\title{
LIETUVOS RESPUBLIKOS ŠVIETIMO POLITIKOS İGYVENDINIMO KONTŪRŲ BRĖŽTIES ASPEKTAS. KAUNO RAJONO ATVEJIS
}

\author{
Paulina Gailiūnienè \\ Ežerèlio pagrindinè mokykla, Kauno r., Lietuva
}

\begin{abstract}
ANOTACIJA
Svarbiausieji Lietuvos švietimo politikos dokumentai teigia, kad švietimas yra prioritetinè šalies sritis ir turi lemti bendrają visuomenès raidą. Kol kas to nèra pasiekta. Kodèl? Taigi, tikslinga peržiūrèti ir aktualizuoti švietimo politikos sampratą, atkreipiant dèmesị ị besikeičiančius šios sampratos erdvès kontūrus. Tyrimo tikslas - išanalizuoti Lietuvos Respublikos švietimo politikos igyvendinimo sistemą, nustatyti esminius jos trūkumus ir pateikti rekomendacijas joms spręsti.
\end{abstract}

Raktažodžiai: švietimo politika, sistema, švietimo politikos igyvendinimas.

\section{IVADAS}

Švietimo politika - tai visuomenès švietimo būklę lemiantys valdžios institucijų sprendimai ir su jais susiję veiksmai. G. Purvaneckienès ir G. Čiužaitès (2010) teigimu, švietimo apibrèžimas nurodo, kad tai yra procesas, kurio metu igyjamos pagrindinès žinios, gebėjimas daryti sprendimus ir argumentuoti teiginius, taip paruošiant intelektualią asmenybę. Šio proceso metu yra igyjamos žinios, gebejjimai, specifiniai ar ypatingi igūdžiai. Pabrèžiama, kad tai yra vienas iš svarbiausių veiksnių, lemiančių tiek visuomenės išsivystymą, tiek paties žmogaus pasiekimus šiuolaikinèje visuomenëje, todèl dažnas atvejis, kuomet visuomenès socialinis išsivystymas matuojamas pasiekimais švietimo sistemoje.

Neabejotina, kad Lietuvoje per dviejų dešimtmečių laikotarpi vyko pozityvūs pokyčiai švietimo politikos planavimo ir jos igyvendinimo srityje (Ališauskas, 2009). Nepaisant to, labai svarbu atskleisti ir aptarti švietimo politikos trūkumus ir akivaizdžias problemas (Aramavičiūtè, 2009; Balevičienè, Urbanovič, 2012). Analizuojant nepriklausomybès laikotarpio švietimo politikos rezultatus (Duoblienè, 2010), matomos problemos: visų lygių švietimo segmentai iki šiol yra nesuderinti, nesulaukiama ryškesnio švietimo kaitos efekto; pastebimas globalizacijos, kaitos, naujovių ignoravimas; mokytojų autoriteto silpnèjimas, socialinès atskirties didèjimas, tèvų ir mokytojų nepasitenkinimas; emigracija; prasta aukštojo mokslo kokybė, mokyklos biurokratizavimas, nepakankamai ir neefektyviai skirstomas bei valdomas švietimo finansavimas, neskaidrumas, užsitęsusi švietimo reforma, neefektyvios švietimo strategijos ir kt. Prastas švietimo politikos proceso suvokimas, švietimo naujovių ignoravimas, skubotas politikų veikimas savo ar savo politinių partijų naudai, neanalizuojant pasekmių tikimybès, verčia analizuoti esamą švietimo politikos igyvendinimo sistemą nuodugniau, stengiantis sukurti ne tik produktyvaus, bet ir dvasinio, moralinio švietimo viziją.

Švietimas - ateities investicijų programa, turinti grịžtamojo ryšio savybę, nepaisant kuriuo lygmeniu jis igyvendinamas, svarbiausia - kokybè ir švietimo prieinamumas. Tarybos ir Komisijos bendroje ataskaitoje apie Europos bendradarbiavimo švietimo ir mokymo srityje strateginès 
programos „ET 2020“ igyvendinimą „Švietimas ir mokymas pažangioje, tvarioje ir integracinèje Europoje“ (2012) pabrèžiama, kad globalūs pokyčiai veikia visų pasaulio šalių visuomenes, tačiau kiekvieną skirtingai, vienur sukeldami didelių problemų, kitur - mažesnių, priklausomai nuo sistemos lankstumo bei atvirumo naujovėms ir pokyčiams. Siekiant priimti globalius iššūkius, kuriami dokumentai, kuriuose aiškiai išdėstyti tikslai, siekiamybės, lūkesčiai. Visgi dažnai kyla problemų švietimo politikos igyvendinimo procese, nes išryškèja tam tikrų kultūrinių, struktūrinių, finansavimo, atsakomybės ir kitų aplinkybių skirtumų.

Nepaisant to, kiekviena šalies vyriausybė, reaguodama i pokyčių ir inovacijų poreikị, kuria nacionalinio lygmens dokumentus. Visgi patiriama įvairių problemų: kai kurios jų sudètingos ir esminès, kitos - mažai reikšmingos. Lietuva - ne išimtis visais lygiais: tarptautiniu, nacionaliniu ir savivaldybių. Kauno rajono savivaldybejje taip pat stengiamasi pasiekti dabartinius šalies švietimo tikslus, igyvendinant svarbiausius švietimo dokumentus, formuojančius valstybės ir savivaldybės švietimo politiką. Ši savivaldybe prioritetine sritimi išskiria švietimą. Analizuojamoje vizijoje reglamentuojama visokeriopo ugdymo svarba ir tikslingumas.

Toliau nagrinèjant švietimo situaciją sparčiai augančiame ir besiplečiančiame Kauno rajone, akivaizdžios dvejopos problemos - priemiesčiuose dèl didèjančio žmonių skaičiaus vaikų darželiuose trūksta vietų, o mokyklų klasès perpildytos. Tuo metu kaimo vietovès mokyklos sujungiamos, o darželiuose pustuštės grupès (Švietimo politika, 2011). Kauno rajono savivaldybė mokyklų reorganizaciniais klausimais taip pat patiria sunkumų. Likviduojant ar sujungiant mokyklas, moksleiviai yra priversti ị mokyklą vykti dešimtis kilometrų, išgyventi adaptacinius procesus, kaimai pasmerkti žlugimui, o reorganizuotų mokyklų pedagogai netenka darbo.

Kalbant apie ugdymo kokybę ir aplinkos gerinimą, pastebimi teigiami pokyčiai: naujos, renovuotos, nauja ịranga ir baldais aprūpintos ugdymo ịstaigos, modernizuotos bibliotekos, klasès, aprūpintos kompiuteriais (Kauno rajono vietos plètros 2007-2013 m. strategija, 2008). Visgi akivaizdu, kad tokiam skaičiui mokyklų visapusiškai aprūpinti mokymo priemonėmis ir invetoriumi reikalingos didelès lèšos, todèl šis procesas vyksta pamažu, skatinamas nebiudžetinių lèšu pritraukimas ị mokymo ịstaigas.

Išanalizuota informacija leidžia teigti, kad esama LR švietimo politikos igyvendinimo sistema nèra pakankamai analizuojama ir galima daryti prielaidas, kad nèra efektyvi.

Tyrimo tikslas - išanalizuoti Lietuvos Respublikos švietimo politikos igyvendinimo sistemą, nustatyti esminius jos trūkumus ir pateikti rekomendacijas joms spręsti.

Tyrimo objektas - Lietuvos švietimo politikos igyvendinimas.

\section{METODIKA}

Tyrimo metodų pagrindimas ir apibūdinimas. Tyrimo tikslui pasiekti buvo pasinaudota interviu apklausos metodu. Tyrimas atliktas 2016 m. kovo mènesi Kauno mieste ir rajone. Ekspertai buvo pasirinkti pagal jų atstovaujamą sritị, vietovę. Taip pat buvo pasitelkta mokslininkų nuomonė analizuojamų skyrių segmentams pagrịsti. Iš viso apklausti šeši ekspertai: du mokslininkai, du savivaldybès ir du administracinio lygmens atstovai. Apklausa vyko iš anksto individualiai susitarus susitikti su ekspertu. Respondentai supažindinti su interviu tikslais, tyrimo tema. Apklausos metu 
buvo laikomasi savanoriškumo, konfidencialumo, kitų etinių principų. Apklausiant respondentus vidutiniškai buvo užtrunkama 30-45 min.

Apklausos instrumentas - interviu klausimynas, sudarytas siekiant sužinoti ekspertų nuomonę kiekvienos analizuojamos srities atžvilgiu. Klausimynas sudarytas iš trijų klausimų blokų: pirmaisiais klausimais (1-3 kl.) buvo siekiama sužinoti asmeninę ekspertų informaciją (darbo stažas, pareigos, dalyvavimo formuojant švietimą lygis); antrame klausimų bloke (4-18 k1.) pateikiami LR švietimo politikos igyvendinimo klausimai kiekvienos darbe analizuojamos srities aspektais; trečiame (1933 kl.) - pateikiami Kauno rajono bendrojo ugdymo igyvendinimo sistemos klausimai kiekvienos darbe analizuojamos srities aspektais.

Gauti duomenys buvo susisteminti ir pateikti pagal analizuojamas darbo sritis kaip praktinis teorinių dalių pagrindimas.

Siekiant užtikrinti ekspertų konfidencialumą, pasinaudota duomentų užkodavimo metodu: ekspertas A-F.

\section{TYRIMO REZULTATAI IR APTARIMAS}

Viešoji politika - sudėtingas procesas, apimantis ịvairias definicijas. Viešosios politikos proceso pakopos, elementai ir proceso ryšys su politikos fazėmis apibūdina viešosios politikos sandaros sudėtingumo lygị. Tai įrodo, kad viešoji politika ir viešosios politikos ịgyvendinimas yra vienas sisteminis darinys, turintis stiprų ryši ir pasižymintis jautrumu bet kokiems pokyčiams.

Sistemiškumas bei jautrumas globaliems švietimo politikos pokyčiams parodo ir švietimo politikos igyvendinimą - ši sritis yra sudètingų procesų visuma, ir šie procesai vienas su kitu yra glaudžiai susiję. Akcentuojama, kad pokyčiai šioje srityje yra neišvengiami, impulsyvūs ir neplanuoti, todèl suvaldyti bei numatyti švietimo politikos procesą ir teigti, kad tam tikri priimami sprendimai bei igyvendinami veiksmai yra inovatyvūs, negalima.

Akivaizdu, kad Lietuvoje valdantieji periodiškai išbando daugybę švietimo politikos igyvendinimo metodų ir priemonių, tačiau, kaip rodo praktika, dauguma jų nepatenkina lūkesčių. Patyrus nesėkmę, tikimasi, kad klaidos bus atidžiai išstudijuotos, o tolesni veiksmai nuodugniai suplanuoti, tačiau esti priešingai. Pasikeitus valdžiai ir atejjus naujos kadencijos laikotarpiui, viskas kartojasi.

Lietuva yra imli naujovèms ir siekia, kad teikiamomis švietimo ir mokymo paslaugomis būtu reaguojama ì kokybės užtikrinimo mechanizmus ir iniciatyvas, orientuojamasi ị darbo rinkoje reikalingas kompetencijas. Tačiau dažnai iškyla sunkumų - nepakankamas finansavimas, netinkamas jo skirstymas, teisinio reglamentavimo trūkumai ar pan. Teisiniu požiūriu sistema nestabili ir neaiški, o pataisų tikslai ir uždaviniai nekonkretūs. Taip pat pastebimas nacionalinio lygio institucijų vengimas prisiimti atsakomybę už klaidas švietimo srityje - tai perduodama savivaldybėms. Tokie reiškiniai kartosis, kol tarpinstitucinis bendravimas modifikuosis iš paviršutiniško ị kokybišką.

Sunkumai Lietuvos švietimo srityje egzistuoja- pateikiama informacija netiksli, neigyvendinami politinių partijų programų tikslai, trūksta finansavimo, yra mokyklų bazès, tinklo, pedagogų personalo, ugdymo ir kt. problemų. Jos yra aiškios ir stengiamasi jas sušvelninti ar išspręti, 
bet net ir problemų šalinimo, jų sprendimo etapu kyla sunkumų. Taip yra dèl to, kad neužtikrinamas problemų sprendimo programų tęstinumas, tolesnė prevencija, pakankamas finansavimas ir kontrolè, pakartotinè prevencija. Taip pat pasigendama paskirstymo už ịvykdytas / neịvykdytas užduotis skaidrumo ir atsakomybès.

Kauno rajono savivaldybė nuosekliai laikosi nacionalinio lygmens dokumentų tikslų ir prioritetų, formuodama individualius strateginius veiklos tikslus. Taip pat yra reglamentavusi kelis svarbiausius rajono reikšmės dokumentus (veiklos reglamentą ir nuostatus).

Kauno rajono savivaldybès atveju švietimo politikos igyvendinimo funkcijos yra aiškiai paskirstytos, nubrèžta atskaitingumo ir pavaldumo riba. Pastebimas skirtingų rajono plètros reguliavimo poreikis - priemiesčiuose daugejjant gyventojų, mokyklose ir vaikų darželiuose trūksta vietų, tolimesnèse vietovėse - situacija priešinga.

Finansiniu požiūriu yra šios problemos: trūksta finansavimo, neskaidrus administravimas, neefektyvus mokinio krepšelio paskirstymas ir pan.

Problemos tarppartiniu požiūriu - konkuravimas ir politinès kovos. Taip pat nè viena partija nepateikia išsamaus plano numatant konkrečių sričių pataisas, pabrěžiant svarius pakeitimų motyvus, pasinaudojant konkrečių duomenų rodikliais, analizès išvadomis.

Pedagoginio personalo požiūriu, Kauno rajonas susiduria su senstančios visuomenès ir darbuotojų problema.

Neetiško elgesio situacijų pasitaiko retai, tačiau i tai pagal galimybes yra reaguojama, taikomos sankcijos.

\section{IŠVADOS IR PERSPEKTYVOS}

Nustatyta, kad esama LR švietimo politikos igyvendinimo sistema nèra efektyvi dèl nepakankamo švietimo ịstaigų finansavimo, netinkamos jo skirstymo metodikos, nacionalinio lygmens institucijų vengimo prisiimti atsakomybę už klaidas, nacionalinès informacijos ir tikrovès neatitikimo. Akivaizdžios ir svarbios yra mokyklų bazès, tinklo, pedagogų personalo, ugdymo problemos. Todèl siūloma vadovautis atvirumo ir skaidrumo principu nacionaliniu lygmeniu, laikytis nuoseklumo politikos srityje, tiksliau nusakyti problemiškas sritis, plètoti tarpinstitucini bendradarbiavimą, peržiūrèti mokinio krepšelio sudarymo metodiką, atsižvelgti ị kaimo vietovių mokyklų reikšmę, prioritetą teikiant išsaugojimui. Svarbiausia - švietimą išskirti prioritetine šalies plètros politikos sritimi.

\section{LITERATŪRA}

1. Ališauskas, R. (2009). Lietuvos švietimas: sėkmės įrodymų paieškos. Pedagogika, 95, 13-23.

2. Aramavičiūtè, V. (2009). Lietuvos švietimo politikos transformacijos. Vilnius: Vilniaus universiteto leidykla.

3. Balevičienè, S., Urbanovič, J. (2012). Kas yra gera mokykla? Švietimo problemos analizė, 3 (67), 12.

4. Duoblienė, L. (2010). Švietimo politika ir globalizacija: nacionaliniai ir supranacionaliniai ypatumai. Acta Paedagogica Vilnensia, 25, 69-84. 
5. Kauno rajono vietos pletros 2007-2013 m. strategija. (2008). Kauno rajonas: Kauno rajono vietos veiklos grupè. Prieiga internetu: http://kaunorvvg.lt/lt [žiūrèta 2017-10-07].

6. Purvaneckienè, G., Čiužaitè, G. (2010). Švietimo reformos ir teisingumas. Acta Paedagogica Vilnensia, T. 25, 85-99.

7. Švietimo politika. (2011). Kauno rajono savivaldybè. Prieiga internetu: http://www.smm.lt/naujienos/docs/kalbos/Svietimo_politika_Kauno_raj_savivaldybeje.pdf [žiūrèta 2018-01-27].

8. Tarybos ir Komisijos bendra ataskaita apie Europos bendradarbiavimo švietimo ir mokymo srityje strateginès programos „ET 2020“ igyvendinima „Švietimas ir mokymas pažangioje, tvarioje ir integracineje Europoje“. (2012). Europos Sajungos institucijų, įstaigų ir organų pranešimai: Taryba, Europos Komisija.

\title{
EDUCATIONAL POLICY IMPLEMENTATION CONTOUR DESIGNATION ASPECT IN THE REPUBLIC OF LITHUANIA. KAUNAS DISTRICT CASE
}

\author{
Paulina Gailiūnienè \\ Ežerèlis Primary School, Kaunas district, Lithuania
}

\begin{abstract}
Research background. Education is one of the most important factors which determine society development. Moreover, it is continuously affected by the change of globalization. In Lithuania, during more than two decades, some positive changes took place in forming and carrying out education policy. However, some mistakes and drawbacks were not avoided, such as education segment nonconformity, globalization, changes and innovations ignorance, school's bureaucratization, insufficiently and inefficiently distributed and controlled education funding, inefficient education strategies, the ignorance of innovations, globalization, etc. According to the most important documents of education policy in Lithuania, it has the priority and must determine general society development but still not achieved.

The aim of the research. The purpose of the research is to analyse the realization system of education policy in Lithuania, also identify its main drawbacks and suggest recommendations to solve them as it is expedient to view and update the concept analysis of educational policy, taking more attention to the continuously changing spread contours of this conception. The research object is educational policy implementation in Lithuania.
\end{abstract}

Methodology. The applied research methods were the analysis of theoretical literature, documents, law acts, interviewing the experts and comparative analysis. The research was carried out in March 2016 in Kaunas city and Kaunas district areas. The experts were chosen by the area of expertise and the location. There were six experts: two scientists, two representatives of the Kaunas district municipality and two experts of the administrational level. To ensure the confidentiality of these experts in this research, we used the method of data encryption: experts named "Expert A-F". The main instrument was the interview guide which was made up to know experts' opinions on each analysed area. The received data was systematized and presented in research areas as practical confirmation of the theoretical thesis. 
Results and conclusions. As a result, it was identified that the present realization system of education policy is not effective because of such reasons as the financing shortage in educational institutions, its inappropriate distribution, avoiding taking responsibility for mistakes and giving the incorrect information. Therefore, some problems in school bases, network, teaching staff and trainings are obvious. Moreover, it was offered to guide honest and clear principles, keeping sequence policy, defining problems more precisely, developing co-operation between institutions, reviewing students' financing, taking into account the importance of school maintenance in small villages. The most important part is to distinguish the educational system as a priority in different areas. It should be guided by the implementation of political will.

Keywords: educational policy, system, educational policy implementation. 